\title{
Medijsko opismenjavanje u osnovnoj školi
}

Prethodno priopćenje _ DOI 10.22522/cmr20190139 _ primljeno 12. veljače 2018.

UDK: $003.02: 316.774$

373.3

\section{Marko Alerić}

Filozofski fakultet, Zagreb, Hrvatska.

E-adresa: maleric@ffzg.hr

\section{Martina Kolar Billege}

Učiteljski fakultet, Zagreb, Hrvatska.

E-adresa: mkbillege@gmail.com

\section{Vesna Budinski}

Učiteljski fakultet, Zagreb, Hrvatska.

E-adresa: vbudinski@ufzg.hr

\section{Sažetak}

Medijska pismenost obuhvaća znanje o medijima, ali i recepciju i produkciju medijske poruke. U suvremenom se odgojno-obrazovnom kontekstu, koji podrazumijeva stalnu izloženost djece medijskim sadržajima, pretpostavlja da odgojno-obrazovni programi sadržajno odgovaraju potrebama učenika - primatelja medijskih sadržaja. U radu smo istražili koji su sadržaji predviđeni Nastavnim planom i programom za osnovnu školu (MZOŠ, 2006) i prijedlogom Nacionalnog kurikuluma za Hrvatski jezik (CKR, 2017) te ispitali mišljenje ravnatelja, kao organizatora nastavnoga procesa, o tome koji su učitelji zaduženi za medijsko opismenjavanje u osnovnoj školi. Nadalje u radu problematiziramo inicijalnu osposobljenost nastavnika za nastavu medijske kulture, stavljamo u suodnos pojmove medijska kultura i medijska pismenost te problematiziramo poistovjećivanje uporabe medijskih alata s medijskom pismenošću. Istraživanje je povedeno s pomoću upitnika kojim smo ispitali nositelje medijskoga odgoja i obrazovanja te najčešće zadužene osobe za medijsko opismenjavanje djece u osnovnoj školi. Rezultati istraživanja pokazuju da je 42,19 \% ravnatelja ( $N=192$ ) nezadovoljno programom medijske kulture u osnovnoj školi, 87,31 \% ( $N=197$ ) ravnatelja misli da bi djecu trebali medijski odgajati učitelji i odgojitelji uz roditelje te da su u školi najčešće za medijsko opismenjavanje zaduženi učitelji hrvatskoga jezika (55,1%; N = 187).

Ključne riječi: medijsko opismenjavanje, osnovnoškolsko obrazovanje, digitalni udžbenik 


\section{Uvod}

Krajnji je cilj učenja ostvarivanje postavljenih ishoda učenja, odnosno stjecanje kompetencije kao kombinacije znanja, vještina i stavova. Bez obzira na to što sadržaj pojma kompetencija samo dijelom podrazumijeva i pojam znanje, ipak će „to konkretno znanje poslužiti kao osnova na kojoj će se svako daljnje poučavanje razvijati“ (Brooks, 2012, str. 106). I medijska je pismenost kompetencija koja podrazumijeva ne samo znanje o medijima, nego uključuje i recepciju i produkciju medijske poruke, kao i sposobnost razumijevanja i promišljanja poruke.

U ovom se radu medijska pismenost promatra u osnovnoškolskom odgojno-obrazovnom kontekstu i ističe se važnost medijske pismenosti poučavatelja kao uvjeta za medijsko opismenjavanje učenika.

U Republici Hrvatskoj sadržaji u kojima se obrađuju teme koje pripadaju medijima i medijskom opismenjavanju najuže su povezani s predmetnim područjem medijske kulture u okviru nastavnoga predmeta Hrvatski jezik (MZOŠ, 2006). U tom se predmetnom području dominantno obrađuju teme u vezi s kazalištem, filmom, računalom i internetom jer se, pod pojmom medija u sintagmi medijska pismenost, općenito najčešće misli na suvremene digitalne (elektroničke) medije. Knjiga se, premda također medij, u okviru nastave Hrvatskoga jezika primarno povezuje s područjem književnosti. Međutim, s obzirom na to da je i knjiga medij i da se pristup dekodiranju poruke, u svojoj biti ne razlikuje, dekodiranje medijske poruke u širem smislu, kao cilj medijskog opismenjavanja, ne bi smjelo isključivati dekodiranje poruke pisane (tiskane) riječi. Bez obzira na vrstu medija kojim je poruka posredovana, u odgojno-obrazovnom kontekstu važno je isticati „da komunikacija odgaja i da odgoj komunicira, pa se uvijek valja prisjećati da se komunicirati mora odgovorno, bez obzira na medij kojim se služimo“ (Labaš, 2011, str. 61).

Sveprisutnost medija kao posrednika u prenošenju informacija, osobito digitalnih medija, postavlja nove zahtjeve pred odgojno-obrazovne djelatnike koji su u suodnosu s aktivnim „konzumentima“ medija i medijskih sadržaja. „U dodiru s novim, digitalnim medijima, roditelji i odgajatelji su često, kako smo naveli, razoružani. S jedne strane, svjesni su i znaju da su novi mediji dio svakodnevnog života njihove djece, ali i dio društvene kulture u kojoj žive i djeluju..." (Labaš, 2011, str. 60). Upravo bi zbog toga poučavanju o suvremenim digitalnim medijima, koji su prisutni ne samo $u$ formalnom poučavanju nego i u samostalnom učenju, kao i medijskom opismenjivanju u osnovnoj školi, trebalo 
posvetiti više pozornosti. U vezi s tim nužno se nameće pitanje jesu li naše škole spremne za medijsko opismenjavanje. Prema sadržaju poučavanja u Nastavnom planu i programu za osnovnu školu (MZOŠ, 2006) može se zaključiti da je zastupljenost medijskih sadržaja i sadržaja o medijima, osobito u primarnom obrazovanju, skromna. Zadaće nastavnoga područja medijska kultura jesu:

„osposobljavanje za komunikaciju s medijima: kazalištem, filmom, radijem, tiskom, stripom, računalom, primanje (recepcija) kazališne predstave, filma, radijske i televizijske emisije; osposobljavanje za vrjednovanje radijskih i televizijskih emisija te filmskih ostvarenja“ (MZOŠ, 2006). Utvrđene zadaće trebale bi se postići obradom ovih tema i utvrđivanjem ostvarenih obrazovnih postignuća: „Animirani film: primanje kratkih lutkarskih i crtanih filmova stilski sadržajno primjerenih djetetu; razlikovati lutkarski i crtani film. Lutkarska predstava: doživjeti lutkarsku predstavu; navesti glavne likove; oživiti scensku lutku; izvesti kraći ulomak igrokaza. Knjižnica: upoznati školsku i mjesnu knjižnicu; naučiti posuđivati, čuvati i vraćati knjige; razlikovati knjižnicu od knjižare. Filmska priča: primati (recepcija) primjerene dječje filmove; zamijetiti i odrediti slijed događaja u filmu; ispričati filmsku priču kratkoga crtanog filma; razlikovati glavne i sporedne likove u filmu. Kazalište: primati (recepcija) nekoliko primjerenih kazališnih predstava (prema mogućnostima); razlikovati kazališnu predstavu od filma; razlikovati pozornicu od gledališta. Televizija: izdvojiti iz televizijskoga programa najdražu emisiju, pogledati ju i razgovarati o njoj. Dječji časopisi: upoznavati neke dječje časopise i stripove u njima, čitati ih, razlikovati ih od ostaloga tiska. Dječji film: primati primjerene dječje filmove (recepcija); razlikovati igrani film za djecu od animiranoga filma; ispričati filmsku priču. Radijska emisija: primati radijsku emisiju za djecu; raspravljati o njoj; zamijetiti zvučna izražajna sredstva. Knjižnica - korištenje enciklopedije: pronaći traženu obavijest u dječjoj enciklopediji služeći se kazalom i abecednim redom. Dokumentarni film: primanje primjerenih dokumentarnih filmova (ekološkoga sadržaja, zavičajna tematika) primjerenih učeniku; zamijetiti osnovna obilježja dokumentarnoga filma. Usporedba filma s književnim djelom: primati nekoliko dječjih filmova nastalih na književnome predlošku (recepcija); iskazivati vlastiti doživljaj književnog djela i filma; zamijetiti sličnost i razlike između filma i književnog djela prema kojemu je snimljen. Računalo: razlikovati obavijesne i zabavne mogućnosti računala. Knjižnica - služenje rječnikom i školskim pravopisom: pronaći traženu obavijest $u$ školskome rječniku ili pravopisu služeći se kazalom i abecednim redom (MZOŠ, 2006, str. 25 - 34)“. 
Pitanje je može li obrada navedenih tema i ispunjavanje navedenih obrazovnih postignuća jamčiti ostvarivanje zadaća nastavnog područja medijska kultura, posebno u vezi s nužnošću osposobljavanja učenika za vrednovanje radijskih i televizijskih emisija te filmskih ostvarenja, odnosno za razvoj medijske pismenosti općenito. Medijska kultura u postojećem odgojno-obrazovnom sustavu predviđa samo ograničeno upoznavanje s medijima.

U području medijske pismenosti prijedlog Nacionalnoga kurikuluma nastavnoga predmeta Hrvatski jezik (CKR, 2017) u domeni Kultura i mediji znatno više uključuje ciljeve koji se odnose na medijsku pismenost. U predloženome je dokumentu istaknuto da se ta domena temelji na razumijevanju teksta u različitim društvenim, kulturnim i međukulturnim kontekstima te da se predmetnim područjem potiče razvoj znanja o sebi i drugima, uvažavanje različitih uvjerenja i vrijednosti te se omogućuje djelovanje u društvenoj zajednici. Domena Kultura $i$ mediji obuhvaća „kritički odnos prema medijskim porukama, razumijevanje utjecaja medija i njihovih poruka na društvo i pojedinca; komunikacijske i prezentacijske sposobnosti: stvaranje medijskih poruka i njihovo odgovorno odašiljanje; razumijevanje kulture $s$ gledišta svakodnevnoga života, $\mathrm{s}$ društvenoga gledišta, kulture u odnosu na popularnu kulturu i kulture u odnosu prema književnosti i ostalim umjetnostima te utjecaj kulture na oblikovanje vlastitoga kulturnog identiteta; svijest o jedinstvenosti i vrijednosti različitih mišljenja, stavova i ideja, društava i kultura sa svrhom uspješne komunikacije te razumijevanja drugih i drukčijih“ (CKR, 2017, str. 9). U odgojno-obrazovnim ishodima domene Kultura i mediji istaknuti su: „informacijska pismenost, medijska pismenost, dekonstrukcija medijske poruke, kulturalnost i kulturni događaji“ (CKR, 2017, str. 9). Prema Odluci o donošenju Kurikuluma za nastavni predmet Hrvatski jezik za osnovne škole i gimnazije u Republici Hrvatskoj (NN 10/2019 od 29. siječnja 2019.) predmetno područje Kultura i mediji obuhvaća iste sastavnice kao u prijedlogu CKR-a iz 2017.

Na temelju odgojno-obrazovnih ishoda domene Kultura i mediji može se zaključiti da je znatna pozornost usmjerena na pronalaženje, dekonstrukciju i odašiljanje poruke. Tako u prvi plan dolazi poruka, a ne sredstvo prenošenja poruke. Zgrabljić Rotar (2005) ističe da osim tehnološkog medijskog opismenjavanja, suvremeni koncept medijske pismenosti obuhvaća i učenje o svim medijima (tisku, radiju, televiziji), o njihovim produkcijskim i ekonomskim načelima funkcioniranja zbog čega u medijsko opismenjavanje valja uključiti i učenje o jezicima medija. Nadalje ističe da je velika odgovornost roditelja i nastavnika u osvještavanju utjecaja medija na djecu/učenike koji su medijima svakodnevno izloženi.

Kako bi se postavljeni ciljevi u domeni Kultura i mediji mogli ostvariti, trebalo bi utvrditi 
u kojoj su mjeri učitelji i nastavnici u Republici Hrvatskoj osposobljeni za recepciju i razumijevanje medijskih poruka, kao i za poučavanje učenika o tome sadržaju? U dosadašnjim se istraživanjima pokazalo da gotovo polovica ispitanih nastavnika hrvatskoga jezika ( $\mathrm{N}=49)$,smatra da nemaju dovoljno znanja o medijima da bi o njima mogli predavati $\left(X^{2}=5,43, s s=2, p<0,01\right.$ ) “(Ciboci, Osmančević, 2015, str. 130). Istraživanje Budinski i Kolar Billege (2016, str. 77) pokazalo je da od 73 ispitane učiteljice razredne nastave $(\mathrm{N}=73)$ njih 37 koristi digitalne udžbenike, a 36 ih ne koristi. „U odgovorima ispitanika prevladavaju odgovori koji ukazuju na nedostatak tehničkih uvjeta za služenje

digitalnim udžbenicima. Ispitanici se koriste zvučnim i video zapisima te kvizovima, uglavnom za ponavljanje i uvježbavanje sadržaja.

\subsection{Cilj istraživanja}

U ovom je radu cilj istraživanja bio ispitati mišljenje ravnatelja osnovnih škola, kao osoba zaduženih za provedbu nastave i ostvarivanje Nastavnog plana i programa, o zadovoljstvu programom medijske kulture, o tome tko bi djecu trebao medijski odgajati, tko je u osnovnoj školi najčešće zadužen za medijsko opismenjavanje i koji su nastavnici u osnovnoj školi najčešće zaduženi za medijsko opismenjavanje.

\subsection{Uzorak i postupak}

Istraživanje je provedeno na stručnom skupu ravnatelja osnovnih škola održanom u prosincu 2016. godine u Dubrovniku. U istraživanju je sudjelovalo ukupno 210 ravnatelja. U Republici Hrvatskoj u trenutku provođenja istraživanja bilo je ukupno 877 ravnatelja osnovnih škola. Populacija ravnatelja izabrana je za sudjelovanje u istraživanju s obzirom na to da su ravnatelji zaduženi za organizaciju nastave i provedbu Nastavnoga plana $i$ programa za osnovnu školu. U zaduženja ravnatelja (prema Planu rada ravnatelja u skladu sa Zakonom o odgoju i obrazovanju u osnovnoj i srednjoj školi NN 87/08 i Zakonom o ustanovama NN 76/93) ubrajaju se, uz druge poslove, i: planiranje i programiranje rada, organizacija i koordinacija rada, realizacija planiranog rada škole, praćenje i unapređivanje nastave, stručno usavršavanje ravnatelja i radnika škole. 


\subsection{Istraživački problemi i hipoteze}

P1: Ispitati jesu li ravnatelji zadovoljni programom medijske kulture.

$H_{i}$ : Pretpostavljamo da ravnatelji nisu u dovoljnoj mjeri upoznati s programom medijske kulture.

P2: Ispitati mišljenje ravnatelja o tome tko bi trebao medijski odgajati djecu.

$\mathrm{H}_{2}$ : Pretpostavljamo da ravnatelji misle kako djecu za medijski odgoj trebaju odgajati i roditelji i učitelji/odgojitelji.

P3: Ispitati tko je, prema mišljenju ravnatelja, u školi zadužen za medijsko opismenjavane učenika.

$H_{3}$ : Pretpostavljamo da ravnatelji misle kako su za to područje zaduženi nastavnici Hrvatskoga jezika.

\section{Rezultati i interpretacija}

Slijedi statistička obrada dobivenih odgovora na postavljena pitanjima.

Tablica 1. Rezultati uz postavljeno pitanje o zadovoljstvu ravnatelja programom medijske kulture

$\mathbf{N}=192$

Zadovoljni

Nezadovoljni

Nisu upoznati s programom medijske kulture u osnovnoj školi

\section{Jeste li zadovoljni programom} medijske kulture?

$33,33 \%$

$42,19 \%$

$24,48 \%$

Rezultati u Tablici 1. pokazuju da je 33,33 \% ravnatelja zadovoljno programom medijske kulture, 42,19\% je nezadovoljno, a 24,48 \% nije upoznato s programom medijske kulture. Taj podatak pokazuje da gotovo $1 / 4$ ravnatelja ne zna što se od učenika i učitelja očekuje $u$ području medijske kulture. 
Tablica 2. Rezultati uz postavljeno pitanje o tome tko bi djecu trebao medijski odgajati

\begin{tabular}{l} 
N $=197$ \\
\hline Roditelji \\
Učitelji i odgojitelji \\
Učitelji i odgojitelji uz roditelje
\end{tabular}

\section{Tko bi djecu trebao medijski} odgajati?

Rezultati u Tablici 2. pokazuju da 87,31 \% ravnatelja misli kako su za medijski odgoj djece odgovorni učitelji i odgojitelji uz roditelje. Medijski odgoj podrazumijeva cjelovit odgojnoobrazovni pristup, stoga je u taj proces zaista važno uključiti i roditelje. Svakodnevno komuniciranje u medijskom prostoru zauzima znatno vrijeme u životu djece (osnovnoškolaca).

Tablica 3. Tko je u osnovnoj školi najčešće zadužen za medijsko opismenjavanje?

\begin{tabular}{|c|c|c|c|}
\hline $\mathrm{N}=197$ & \multicolumn{3}{|c|}{$\begin{array}{l}\text { Tko je u osnovnoj školi najčešće zadužen za medijsko } \\
\text { opismenjavanje? }\end{array}$} \\
\hline Stručni suradnici & \multicolumn{3}{|l|}{$23,8 \%$} \\
\hline \multirow{9}{*}{$\begin{array}{l}\text { Nastavnik pojedinog } \\
\text { predmeta }\end{array}$} & \multirow{9}{*}{$71,4 \%$} & \multicolumn{2}{|c|}{$\mathrm{N}=187$ (Kojega nastavnoga predmeta? } \\
\hline & & Hrvatskoga jezika & $55,1 \%$ \\
\hline & & Informatike & $21,9 \%$ \\
\hline & & Stranih jezika & $2,7 \%$ \\
\hline & & Tehničke kulture & $3,2 \%$ \\
\hline & & Razrednici & $3,7 \%$ \\
\hline & & Knjižničari & $5,3 \%$ \\
\hline & & $\begin{array}{l}\text { Učitelji razredne } \\
\text { nastave }\end{array}$ & $5,3 \%$ \\
\hline & & Svi nastavnici & $0,5 \%$ \\
\hline $\begin{array}{l}\text { Djeca se u školi medijski } \\
\text { ne opismenjavaju }\end{array}$ & $4,8 \%$ & & \\
\hline
\end{tabular}

Rezultati u Tablici 3. pokazuju da, kako smo i pretpostavili, 71,4 \% ravnatelja misli da su za medijsko opismenjavanje u školi zaduženi nastavnici pojedinoga nastavnog predmeta. $23,8 \%$ ravnatelja misli da su za to zaduženi stručni suradnici, a 4,8 \% ravnatelja misli da se djeca u školi medijski ne opismenjavaju. Daljnja je analiza pokazala da su to, prema 
mišljenju ravnatelja, najčešće nastavnici hrvatskoga jezika (55,1\%), iako, s obzirom na kompleksnost medijskoga odgoja, za to područje trebaju biti zaduženi svi nastavnici i stručni suradnici. Rezultati nadalje pokazuju da 21,9 \% ravnatelja misli kako medijsko opismenjavanje provode učitelji informatike. Pretpostavljamo da taj dio ispitanika u potpunosti ne razumije razliku između medijske i informatičke pismenosti, ali je taj podatak potrebno dodatno ispitati. Mali postotni udjeli raspoređeni su na učitelje stranih jezika (2,7 \%), tehničke kulture (3,2 \%), razrednike (3,7 \%) i knjižničare (5,3 \%). Rezultati pokazuju da samo 5,3 \% ravnatelja misli kako medijsko opismenjavanje provode učitelji razredne. Naime, učitelji razredne nastave $u$ prilici su sveobuhvatno ( $u$ okviru šest nastavnih predmeta) medijski opismenjavati učenike. To inicira potrebu za temeljitim istraživanjem o tome (1) znaju li ravnatelji što je medijsko opismenjavanje i (2) znaju li ravnatelji da se medijsko opismenjavanje ostvaruje u svim nastavnim predmetima $i$, primjereno dobi učenika, u svim osnovnoškolskim razredima.

\section{Rasprava i zaključalk}

S obzirom na pokazatelje koji su dobiveni ovim istraživanjem može se opravdano postaviti pitanje jesu li ravnatelji škola svjesni važnosti medijskoga odgoja i jesu li spremni poticati medijski odgoj.

S obzirom na aktualnu zakonsku regulativu u odgoju i obrazovanju velika je odgovornost i na autorima udžbenika u izboru i strukturiranju udžbeničkog sadržaja, osobito u digitalnom udžbeniku koji kao multimedijski izvor integrira razne medije, a u kojem su sadržane primjerene i kontrolirane poruke, kao što je to, na primjer, digitalni udžbenik. Digitalni bi udžbenik mogao biti sredstvo, medij koji omogućuje započinjanje razvoja medijske pismenosti primanjem izabrane i kontrolirane medijske poruke. Metodički instrumentarij $\mathrm{u}$ digitalnome udžbeniku utemeljen je na zakonitostima spoznaje $\mathrm{i}$ metodičkim teorijama, sustavima i pristupima. On predstavlja spoj tradicionalnog metodičkog pristupa učenju poštujući spoznaje o učenju i poučavanju, načela induktivnoiskustvenog pristupa te na višim stupnjevima obrazovanja deduktivno-znanstvenog pristupa. Taj instrumentarij prati i suvremene zahtjeve medijske pismenosti učenika i učitelja u 21. stoljeću omogućujući uključivanje raznovrsnih sadržaja za razvoj jezičnih kompetencija i čitalačke pismenosti (Budinsk, Kolar Billege, 2016, str. 83).

U Završnoj je inačici Kurikuluma za nastavni predmet Hrvatski jezik za osnovne škole i gimnazije u Republici Hrvatskoj (NN 10/20199) predviđeno da učenici od 3. razreda 
prepoznaju različite izvore informacija, pa tako i digitalne udžbenike. Digitalni udžbenik, s obzirom na izabrane medijske poruke, stvara medijski eko-sustav (vidi: digitalni eko-sustav u: Jandrić, 2014, str. 37). Dok se koriste digitalnim udžbenikom, učenici su uključeni u ograničeno i usmjereno traženje podataka koje im, s obzirom na to da još nisu medijski pismeni, omogućuje kritičko promišljanje o ponuđenim sadržajima, uočavanje slojevitosti poruke i raspravljanje o tim porukama. I u načelu prosudbe, koje se kao i ostala načela izvodi iz svrhe nastave hrvatskoga jezika i omogućuje ostvarivanje te svrhe, navodi se da učenike treba osposobiti za vrijednosnu prosudbu teksta na njegovoj obavijesnoj, misaonoj, osjećajnoj, estetskoj, gramatičkoj, stilskoj i pravopisnoj razini (Težak, 1996, str. 104). Tijekom ovladavanja inicijalnom informatičkom pismenošću važno je istodobno uključivati odgoj i obrazovanje za informacijsku pismenost, odnosno cjelovitu medijsku pismenost. Od ravnatelja koji medijski odgoj percipiraju kao bitnu sastavnicu odgoja i obrazovanja, može se očekivati podrška za provođenje tih sadržaja.

\section{Popis literature}

- Budinski, V., Kolar Billege, M. (2016). Od zavičajnoga govora do standardnoga hrvatskog jezika uz primjenu metodičkoga instrumentarija u digitalnome udžbeniku, 73-86. U: Celiković, K. (ur.), Dani Balinta Vujkova - dani hrvatske knjige i riječi. Subotica: Hrvatska čitaonica.

- Brooks, D. (2012). Društvena životinja. Skriveni izvori ljubavi karaktera i postignuća. Zagreb: Mozaik knjiga..

- Ciboci. L., Osmančević, L. (2015). Kompetentnost nastavnika hrvatskoga jezika za provođenje medijske kulture u hrvatskim osnovnim školama, 121-138. U: V. Car, L. Turčilo i M. Matović (ur.), Medijska pismenost - preduvjet za odgovorne medije. Sarajevo: Fakultet političkih nauka Univerziteta u Sarajevu.

- Cjelovita kurikularna reforma (2017). Nacionalni kurikulum nastavnog predmeta Hrvatski jezik- prijedlog nakon javne rasprave. Dostupno na: https://mzo.hr/sites/default/files/dokumenti/2017/OBRAZOVANJE/NACION-KURIK/PREDMETNI-KURIK/ hrvatski_jezik.pdf. Preuzeto 17. prosinca 2018.

- Jandrić, P. (2014). Digitalno učenje. Zagreb: Školske novine d. o. o. i Tehničko veleučilište u Zagrebu.

- Labaš, D. (2011). Djeca u svijetu interneta: zatočenici virtualnog svijeta. Pedagoški modeli i otvorena pitanja, 35-64. U: Ciboci, L., Kanižaj, I. i Labaš, D. (ur.), Djeca medija. Od marginalizacije do senzacije. Zagreb: Matica hrvatska.

- Ministarstvo znanosti, obrazovanja i športa (2006). Nastavni plan i program za osnovnu školu. Zagreb.

- Odluka o donošenju Kurikuluma za nastavni predmet Hrvatski jezik za osnovne škole i gimnazije u Republici Hrvatskoj (NN 10/2019. od 29. siječnja 2019.)

- Opačić, N. (2009). Riječi s nahtkasna i kantunala (preko noćnog ormarića). Zagreb: Profil multimedia.

- Težak, S. (1996). Teorija i praksa nastave hrvatskoga jezika 1. Zagreb: Školska knjiga

- Zgrabljić Rotar, N. (2005). Mediji - medijska pismenost, medijski sadržaji i medijski utjecaji, 10-33. U: Zgrabljić Rotar, N. (ur.), Medijska pismenost i civilno društvo. Sarajevo: Mediacentar. 


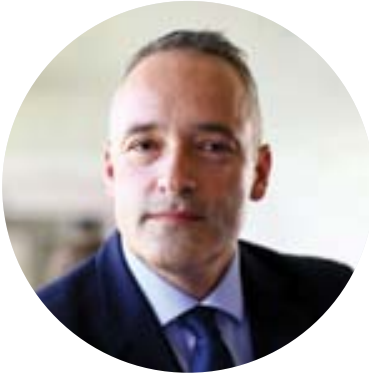

Marko Alerić

Izv. prof. dr. sc. Marko Alerić doktorirao je na temu Normativna morfologija u nastavi hrvatskoga jezika. U ak. godini 2016./2017. obnašatelj je dužnosti prodekana za nastavu i studente na Filozofskom fakultetu Sveučilišta u Zagrebu. Održavao je predavanja i seminare iz kolegija Teorija jezika, Hrvatski standardni jezik, Metodika nastave hrvatskoga jezika, Pravogovor u nastavi, Naglasci u hrvatskom jeziku, Jezično-stilske vježbe (Govoreno i pisano izražavanje), Normativna gramatika u nastavi, Teorija i praksa jezičnih odstupanja. Napisao je više udžbenika, priručnika i znanstvenih radova. Bio je član Nacionalnog vijeća za odgoj i obrazovanje RH. Član je Povjerenstva za sveučilišnu nastavnu literaturu Sveučilišta u Zagrebu. Stručni je suradnik Hrvatske radio-televizije.

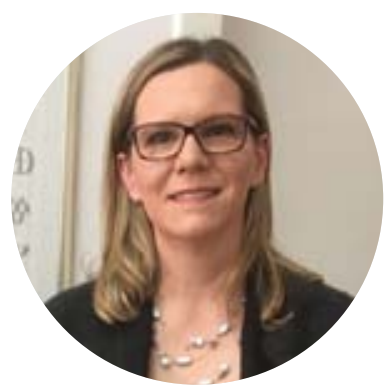

\section{Martina Kolar Billege}

Doc. dr. sc. Martina Kolar Billege doktorirala je na temu Metodički pristup određivanju sadržaja poučavanja i kognitivnih ishoda učenja za nastavni predmet Hrvatski jezik u primarnom obrazovanju. Nositeljica je kolegija Metodika hrvatskoga jezika, Suvremene metodičke teorije, Uređivanje vrtićkih i školskih novina te Vrednovanje $\mathrm{u}$ hrvatskome jeziku. Objavila je više od dvadeset znanstvenih radova iz područja metodike hrvatskoga jezika. Suautorica je udžbenika od 2006. godine (uključujući i digitalne udžbenike od 2014. godine), metodičkih priručnika $i$ ispita za hrvatski jezik u primarnom obrazovanju. Sudjeluje na znanstvenim i stručnim skupovima u zemlji i inozemstvu. Stalna je sudska vještakinja za autorska prava $\mathrm{u}$ autorstvu udžbenika i procjenu znanstvenih radova.

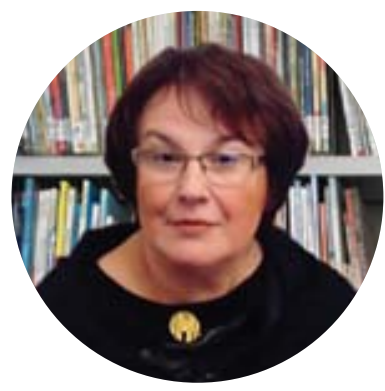

\section{Vesna Budinski}

Doc. dr. sc. Vesna Budinski doktorirala je na temu Metodički sadržajno-vremenski optimum poučavanja početnog čitanja i pisanja na hrvatskom jeziku. Nositeljica je kolegija Metodika hrvatskoga jezika, Suvremene metodičke teorije i Strategije i metode početnoga čitanja i pisanja. Autorica je i suautorica je više znanstvenih radova, udžbenika i metodičkih priručnika za nastavni predmet Hrvatski jezik u primarnom obrazovanju. Sudjeluje na znanstvenim skupovima u zemlji i inozemstvu. Dobitnica je državne nagrade „Ivan Filipović“ za 2008. godinu. Predstojnica je Katedre za metodike Učiteljskog fakulteta u Zagrebu. Članica je uredništva znanstvenoga časopisa Napredak. Sudjeluje kao predavačica u stručnom usavršavanju učitelja u organizaciji Agencije za odgoj i obrazovanje od 2000. godine. 